\title{
Columnar Cell Change of the Breast
}

National Cancer Institute

\section{Source}

National Cancer Institute. Columnar Cell Change of the Breast. NCI Thesaurus. Code C54181.

A columnar cell lesion characterized by the presence of enlarged terminal ductal lobular units with dilated acini. The acini are lined by one or two layers of columnar epithelial cells. Apical cytoplasmic snouts may be present, but they are not prominent. Secretions may be present in the lumina of the dilated acini. 